\title{
KEEFEKTIFAN TEAM TEACHING PENDIDIK \\ PROGRAM PENDIDIKAN DAN PENGEMBANGAN ANAK USIA DINI (PPAUD) DI KABUPATEN KULON PROGO
}

\section{THE EFFECTIVENESS OF TEAM TEACHING OF EARLY CHILDHOOD EDUCATION PROGRAM EDUCATORS IN KULONPROGO REGENCY}

\author{
Benny Erifiani, Puji Yanti Fauziah \\ Dinas Pendidikan Kabupaten Kulon Progo, Universitas Negeri Yogyakarta \\ ben_view@yahoo.com, pujiyantif@gmail.com
}

\begin{abstract}
Abstrak
Penelitian ini bertujuan untuk mengetahui keefektifan: (1) Pemahaman, perencanaan, pelaksanaan, dan evaluasi pendidik program PPAUD tentang team teaching (2) hasil team teaching, dan (3) faktor pendukung dan penghambat keefektifan team teaching. Penelitian ini merupakan penelitian evaluasi dengan logic models menggunakan pendekatan kualitatif dan kuantitatif. Subjek penelitian 65 orang pendidik. Instrumen pengumpulan data yang digunakan adalah kuesioner, lembar observasi, dan pedoman wawancara. Teknik pengumpulan data yang digunakan adalah studi dokumen, wawancara, observasi dan kuesioner. Data dianalisis secara deskriptif. Hasil penelitian menunjukkan bahwa pemahaman, perencanaan, pelaksanaan, dan evaluasi team teaching efektif. Team teaching memberikan hasil positif terhadap anak, dan terdapat faktor pendukung team teaching meliputi: rasio peserta didik dan pendidik, ketersediaan sarana prasarana, rekan pendidik yang terbuka dan mempunyai keinginan kerja sama, ketercapaian tumbuh kembang anak, proses administrasi mudah dan lengkap serta bertambahnya kemampuan pendidik. Faktor penghambat meliputi: jumlah pendidik sedikit dan fasilitas sarana prasarana terbatas.
\end{abstract}

Kata Kunci: keefektifan, team teaching, PAUD

\section{Abstract}

This study aims to investigate: (1) the effectiveness of: the educators' understanding of team teaching, the educators' planning in team teaching, the implementation of team teaching, and the evaluation of team teaching; (2) the result of team teaching; and (3) supporting and inhibiting factors of team teaching in Early Childhood Education Program educators in Kulon Progo Regency. This study was an evaluation study using quantitative and qualitative approaches. The evaluation model used was the logic models. The research subject were 80 educator's with 65 educators Data were collected by means of questionnaires, observation, and interview. The technique of data analysis used was descriptive. The results show that: (1) the educators' understanding of team teaching is quite effective with a score of 1.52 or $89 \%$, (2) the educators' planning in team teaching is very effective with a score of 2.79 or $93 \%$, (3) the implementation of team teaching is very effective with a score of 2.91 or $97.1 \%$, (4) the evaluation of team teaching tremendously effective with a gained score of 2.28 or $99.3 \%$, (5) the team teaching gives a positive effect to the children according to administrators' and parents' point of view, (6) the supporting factors of team teaching are: (a) the educator and children ratio, (b) the availability of infrastructure and facilities, (c) open minded and good willing to cooperate of educators' partner, (d) the best possibility of children development, (e) the convenient and comprehensive administration process, and (f) the increase of educator's competencies by interaction and team teaching. The inhibiting factors of team teaching are: (a). the limitation of the number of educators, and (b) the limitation of infrastructure and facilities.

Keywords: effectiveness, team teaching, early childhood education 


\section{PENDAHULUAN}

Pendidikan anak usia dini adalah suatu upaya pembinaan yang ditujukan kepada anak sejak lahir sampai dengan usia enam tahun yang dilakukan melalui pemberian rangsangan pendidikan untuk membantu pertumbuhan jasmani dan rohani agar anak memiliki kesiapan dalam memasuki pendidikan selanjutnya. PAUD dibedakan menjadi PAUD formal, nonformal dan informal. PAUD formal meliputi Taman Kanak-Kanak (TK) dan Raudhatul Athfal $(R A)$. PAUD nonformal dibedakan menjadi Taman Penitipan Anak (TPA), Kelompok Bermain (KB) dan Satuan PAUD Sejenis (SPS). Adapun PAUD informal adalah pendidikan yang diperoleh anak di lingkungan keluarga maupun lingkungannya.

Pendidikan anak usia dini (PAUD) menjadi hal yang luar biasa berkembang di masyarakat. Perhatian pemerintah terhadap perkembangan layanan PAUD menjadi besar dengan diperluasnya akses dan dicanangkannya program pada PAUD nonformal. Pemerintah Republik Indonesia bekerja sama dengan Kerajaan Belanda dan World Bank meluncurkan Program Pendidikan dan Pengembangan Anak Usia Dini (PPAUD) pda ${ }^{1}$ Kabupaten terpilih di Indonesia pada tahun 2006. Adapun kelanjutan tahapan dari peluncuran program tersebut adalah sosialisasi dan perumusan kebijakan teknis dan pelaksanaan program dimulai tahun 2008 dan selesai tahun 2013.

Kabupaten Kulon Progo menjadi salah satu dari 51 kabupaten se-Indonesia yang mendapatkan program PPAUD. Program PPAUD dilaksanakan tidak di semua desa di Kulon Progo. Akan tetapi dari jumlah keseluruhan desa yang ada, yaitu 88 desa menjalani proses seleksi berdasarkan kriteria yang diberikan World Bank, dan hanya 60 desa yang memenuhi kualifikasi untuk memperoleh dana program PPAUD. Melalui program ini diharapkan partisipasi orang tua dalam mengikutsertakan putra-putrinya ke PAUD dapat meningkat.

Desa sasaran program PPAUD dibagi menjadi tiga gelombang sesuai dengan desain pendampingan oleh tim fasilitator masyarakat. Program PPAUD dilaksanakan di sebelas kecamatan yang memenuhi kriteria, sesuai dengan penilaian oleh World Bank. Kriteria penilaian didasarkan pada jumlah potensi anak usia dini terbanyak dan dari jumlah kepala keluarga miskin terbanyak serta potensi pasangan usia subur dan ibu hamil.

Program PPAUD mempunyai tujuan yaitu: (1) mempromosikan layanan yang terdesentralisasi dan berbasis masyarakat, serta menguatkan kemampuan masyarakat pada layanan tersebut; (2) menargetkan keluarga dan masyarakat miskin untuk pembiayaan penyediaan layanan PPAUD; dan (3) menguatkan kemampuan sistem pengelolaan dalam perencanaan, penjaminan kualitas, serta pemantauan dan evaluasi tingkat pusat, provinsi dan kabupaten (POL, 2008, p.1).

Program PPAUD di Kabupaten Kulon Progo sudah berjalan dan berakhir pada bulan Agustus 2013. Penyelenggaraan program selama tiga tahun yang sudah berjalan belum dapat diketahui secara nyata ketercapaian tujuan program. Perencanaan, pelaksanaan, pembinaan dan monitoring yang telah dilakukan diharapkan dapat menjadi sumber data dalam mengetahui ketercapaian tujuan program.

Unsur yang terlibat dalam program meliputi: pengelola program tingkat kabupaten/District Project Implementing Unit (DPIU), Tim Fasilitator Masyarakat (TFM), Tim Pengelola Kegiatan (TPK), Tenaga Didik (Tendik), Petugas PPAUD/Community Driven Worker $(C D W)$ dan Tim Pemantau Program (TPP). DPIU merupakan pengelola tingkat kabupaten yang terdiri dari pegawai dinas pendidikan baik staff maupun penilik. TFM merupakan unsur luar yang direkrut dinas pendidikan sesuai dengan prosedur program. Adapun TPK, tendik, CDW dan TPP merupakan unsur masyarakat dalam internal desa yang mendapatkan program PPAUD. Pengelola dibentuk dengan pendekatan pemberdayaan oleh TFM bersama dengan DPIU.

Penyelenggaraan layanan PPAUD merupakan layanan pendidikan holistik yang memberikan pendidikan, pelayanan kesehatan, dan kegiatan pengasuhan bersama serta parenting. Kegiatan tersebut 
difasilitasi oleh tenaga didik dan petugas PPAUD. Adapun penjagaan hubungan dan penjaringan mitra menjadi tanggung jawab pengelola sehingga kerja sama dari berbagai pihak dapat berlangsung.

Jumlah keseluruhan TPK yang ada dalam satu kabupaten adalah 120 lembaga yang tersebar pada 6o desa (Data Monev TFM, 2011). Penyelenggaraan layanan program PPAUD 78\% (94 TPK) dilaksanakan rumah kepala pedukuhan, 10\% (24 TPK) berada di gedung PNPM dan sisanya $2 \%$ (2 TPK) berada di balai pedukuhan (Data Monev TFM tahun 2010). Ketersediaan fasilitas pembelajaran sangat minim, luas ruangan rata-rata adalah $30 \mathrm{~m}^{2}$ dengan jumlah anak di atas 20. Fasilitas lain seperti MCK 90\% ada dan belum layak. Adapun APE dan sarana pembelajaran lain sangat terbatas mengingat dana yang digulirkan kecil untuk mendanai anak dalam satu wilayah TPK. Dana 90 juta dialokasikan untuk satu TPK dengan pelaksanaan anggaran selama tiga tahun dengan rerata anak dalam satu TPK adalah 130 anak (Data Primer TFM tahun 2010). Kondisi di atas prasarana dan sarana, sangat timpang. Imbangan antara jumlah anak dengan luas ruangan serta fasilitas kesehatan dan kebersihan tidak selaras.

Penyelenggaraan kegiatan layanan PPAUD dilaksanakan minimal dua kali dalam sepekan untuk layanan PAUD Pusat dan minimal satu kali sepekan untuk layanan PAUD Kunjung sesuai dengan aturan program. Penentuan jumlah hari layanan dalam sepekan ditentukan berdasarkan usulan masyarakat yang dibahas dan diputuskan dalam forum musyawarah desa. Masyarakat pada umumnya mengambil batasan minimal dari ketentuan program yaitu sepekan dua kali ataupun sepekan satu kali. Intensitas pelaksanaan layanan PPAUD (jumlah hari dan dua jam sekali pertemuan) yang minim menjadikan kemampuan peserta didik belum dapat terstimulasi maksimal. Lembaga-lembaga tersebut melaksanakan kegiatan dengan rata-rata tiap anak mendapatkan layanan pembelajaran sejumlah 2-6 jam dalam sepekan dengan semua rentang usia anak (Data Monev TFM, 2011). Hal ini dapat menunjukkan rendahnya kualitas layanan yang diperoleh anak.
Penyelenggaraan PAUD tidak dapat terlepas dari partisipasi orangtua. Orangtua mempunyai peran dalam mengantarkan peserta didik ke tempat layanan. Berdasarkan pengamatan, partisipasi orangtua masih minim. Hal ini disebabkan belum tingginya pemahaman orangtua tentang pentingnya PAUD. Data monev tahun 2011, menunjukkan bahwa baru 65\% (21.450 orang) orangtua paham akan pentingnya PAUD untuk anak mereka.

Program PPAUD merupakan program Direktorat Pembinaan PAUD dan di tingkat kabupaten berada di bawah bimbingan dan binaan Dinas Pendidikan. Dinas Pendidikan mempunyai kewajiban melakukan monitoring dan evaluasi. Monitoring dan evaluasi memang telah dilaksanakan. Akan tetapi instrumen monitoring dan evaluasi yang sudah diisikan kepada pengelola program di tingkat desa tidak banyak ditindaklanjuti oleh petugas pemonitor. Temuan-temuan dari lapangan ini sangat berharga untuk dianalisis dan sebagai bahan evaluasi, akan tetapi hanya didiamkan, tentu saja hal ini tidak memberikan dampak dalam perbaikan pelaksanaan program.

Unsur lain yang terlibat dalam pembelajaran dan berperan utama adalah pendidik. Pendidik merupakan istilah yang hakikatnya erat dengan istilah guru. Pendidik PAUD pada jalur pendidikan formal terdiri atas guru dan guru pendamping; sedangkan pendidik PAUD pada jalur pendidikan nonformal terdiri atas guru, guru pendamping, dan pengasuh (Permen 58 tahun 2009, p.12).

Program PPAUD mensyaratkan warga masyarakat yang dapat menjadi pendidik adalah warga yang mempunyai ijazah minimal SMA, sayang terhadap anak-anak dan ikhlas tidak mengharapkan gaji yang besar. Longgarnya persyaratan ini menjadikan berbagai macam latar belakang pendidikan pendidik PAUD sangat beragam. Berdasarkan data yang diperoleh dari monev dapat dilihat sebagai berikut; jumlah keseluruhan tendik dan CDW adalah 240 orang dengan latar belakang pendidikan SMA, S1, dan Diploma (Dinas Pendidikan, 2011). Terkait dengan kegiatan belajar pendidik perlu menyediakan berbagai macam per- 
alatan, merencanakan aktivitas dan memberikan kesempatan pada anak untuk melatih berbagai aspek perkembangan mereka (Fridani, 2009, p.9).

Pendidik mempunyai peran-peran penting seperti yang diungkapkan Sujiono (2009, p.13). Peran tersebut adalah: peran guru dalam berinteraksi; peran guru dalam pengasuhan; peran guru dalam mengatur tekanan/stress; peran guru dalam memberikan fasilitasi; peran guru dalam perencanaan peran guru dalam pengayaan; peran guru dalam menangani masalah; peran guru dalam pembelajaran dan; peran guru dalam bimbingan dan pemeliharaan.

Latar belakang pendidikan yang beragam jelas memberikan pengaruh terhadap kemampuan pendidik. Desain program memberikan pendidikan dan pelatihan kepada pendidik yang terlibat dalam pengelola tingkat desa selama dua ratus jam pelatihan dengan tujuan agar kemampuan pendidik dapat berada dalam tingkat yang sama. Hasil dari diklat, diharapkan pendidik mempunyai pemahaman dan kemampuan melaksanakan pembelajaran. Namun hal yang terjadi di lapangan sangat beragam. Sebagian pendidik melaksanakan pembelajaran sesuai dengan standar program, namun tidak sedikit pendidik yang tidak melaksanakan pembelajaran sesuai standar program.

Dalam satu pengelola kegiatan terdapat dua orang pendidik yang dilatih dari program untuk kemudian menangani kegiatan layanan PPAUD. Pendidik merupakan unsur yang terlibat langsung dengan anak usia dini dan orangtua yang mengantarkan atau menunggu anak mereka dalam mengikuti layanan PAUD. Interaksi dan komunikasi yang terjadi dapat menjadi hal positif bagi anak dan orangtua maupun efek sebaliknya. Kepercayaan orangtua terhadap layanan PAUD akan bermula dari interaksi pendidik dengan anak, dan berlanjut dari interaksi pendidik dengan orangtua. Kerja sama internal pendidik dalam menyelenggarakan layanan PAUD dan interaksi terhadap anak dan menjaga hubungan dengan orangtua anak usia dini menjadi penting untuk dilihat keefektifannya.
Pendidik ini akan melakukan perencanaan, pelaksanaan dan evaluasi pembelajaran dan pelayanan secara bersama-sama atau melaksanakan team teaching. Kegiatan team teaching sudah berjalan, akan tetapi belum diketahui seberapa efektif hal yang telah mereka lakukan tersebut. Pemahaman pendidik tentang team teaching, perencanaan tim yang mereka lakukan, pelaksanaan, dan evaluasi team teaching yang telah dilakukan belum diketahui keefektifannya. Juga belum diketahui kualitas hasil team teaching terhadap anak usia dini dan kualitas layanan ideal yang diharapkan dalam layanan PAUD yang telah mereka lakukan tersebut. Faktor-faktor pendukung atau penghambat keefektifan team teaching menjadi hal yang perlu diketahui pula. Faktor pendukung perlu diketahui sebagai langkah optimalisasi team teaching, sedangkan faktor penghambat perlu diminimalkan agar team teaching dapat berjalan dengan efektif.

Team teaching can be defined as a group of two or more teachers working together to plan, conduct and evaluate the learning activities for the same group of learners (Goetz, 200o, p.1). Pengertian lain tentang team teaching menurut Beggs (1964, p.16) adalah, team teaching maybe defined as an arrangement whereby two or more than teacher, with or without teacher aides, cooperatively plan, instruct and evaluate one or more class groups in an appropriate instructional space and given length of time, so as to take advantage of the special competencies of team members.

Model team teaching beragam. Menurut Goetz (2000, p.2) terdapat dua kategori dari team teaching yaitu kategori A dan kategori B. Kategori A adalah "two or more instructors are teaching the same students at the same time within the same classroom; sedangkan kategori B "the instructors work together but do not necessarily teach the same groups of students nor necessarily teach at the same time.

Manfaat team teaching, adalah; each team member can contribute to lesson based upon his or her strengths (Nevin, 2009, p.61). Adapun tantangan dari pelaksanaan team teaching untuk guru adalah: the time required to function effectively as a team may 
increase the probability of personality conflicts arising between team members. On one hand, these differences may lead to renewed insights and understanding between the team members, but on the other hand, an ireparable rift between the colleagues may result. When mediation cannot mend the situation, separation is often the best alternative, as students can sense the negative tension between the educators in front of them and this awkward situation will detract from the students' learning (Goetz, 200o, p.7).

Team teaching pendidik ini menentukan kualitas pelayanan PAUD di TPK. Sering muncul keluhan dari pendidik bahwa mitranya tidak dapat diajak kerja sama dalam membuat perencanaan pembelajaran. Pelaksanaan layanan sering ada pelimpahan tanggungjawab antar pendidik satu kepada mitranya sehingga porsi beban tidak sama. Dari 240 pendidik program PPAUD yang ada, berdasarkan data monev sejumlah 100 pendidik melakukan perencanaan pembelajaran sesuai dengan acuan, 100 orang pendidik melaksanakan pembelajaran dengan menggunakan rencana tahun lalu atau tahun sebelumnya tanpa membuat up date perencanaan, sedangkan sisanya 40 orang pendidik melakukan pembelajaran tanpa perencanaan. Kondisi ini jelas memerihatinkan mengingat peran penting pendidik dalam menstimulasi pertumbuhan dan perkembangan anak juga kecerdasan anak. Layanan pendidikan yang terkesan seadanya tidak akan menghasilkan pendidikan yang berkualitas. Pendidik sebagai unsur utama yang telibat langsung dengan anak usia dini mempunyai peran penting terhadap kualitas pembelajaran dan terstimulasinya tumbuh kembang anak yang optimal.

Menurut Morrison PAUD adalah "services for children from birth through age eight in part day and full day group programs in centers, homes, and institutions; kindergartens and primary schools, and recreational programs" (1976, p.4). PAUD merupakan layanan untuk anak sejak lahir sampai dengan usia delapan tahun, yang meliputi layanan setengah hari maupun sehari penuh di suatu tempat yang terpusat, di rumah ataupun di institusi, baik di jalur Taman Kanak-kanak, Sekolah Dasar maupun Prog- ram-program Rekreasi. Batasan usia anak dikatakan sebagai anak usia dini adalah delapan tahun. Pembelajaran di PAUD minimal memenuhi kriteria sebagai berikut: (1). Memberikan kesempatan bermain kepada anak untuk dapat melakukan penyelidikan dan penemuan, (2). Mengajar dan memertimbangkan stimulasi kecerdasan ganda, (3). Memenuhi kebutuhan perkembangan anak usia dini (Nielsen, 2008, p.6).

Pendidik anak usia dini adalah profesional yang bertugas merencanakan, melaksanakan proses pembelajaran, dan menilai hasil pembelajaran, serta melakukan pembimbingan, pengasuhan dan perlindungan anak didik. Fokus perencanaan yang dilakukan pendidik PAUD sebagaimana pendapat Dopyera, 1993, p.235, adalah teacher planning focuses on finding ways to stimulate and encourage children to connect new with previous experiences, to experiment, to categorize, to theorize, and to draw inferences.

Penelitian ini bertujuan untuk mengetahui (1) keefektifan: pemahaman, perencanaan, pelaksanaan, evaluasi pendidik program PPAUD tentang team teaching; (2) hasil team teaching; (3) faktor pendukung dan penghambat keefektifan team teaching.

Dari penelitian ini diharapkan lembaga mengetahui kualitas layanan yang diberikan kepada masyarakat sehingga lembaga dapat merencanakan program layanan yang lebih baik. Manfaat lain untuk pendidik, pendidik lembaga dapat melakukan evaluasi atas team teaching yang dilakukan. Adapun manfaat untuk program adalah diketahuinya pelaksanaan program di desa sasaran yang nantinya menjadi dasar evaluasi bagi perencanaan program selanjutnya.

Evaluasi adalah kegiatan untuk mengumpulkan informasi tentang bekerjanya sesuatu, yang selanjutnya informasi tersebut digunakan untuk menentukan alternatif yang tepat dalam mengambil suatu keputusan (Arikunto, 2010, p.2). Pendapat lain mengungkapkan bahwa evaluasi adalah kegiatan sistematis untuk mengumpulkan, mengolah dan menyajikan data atau informasi yang diperlukan sebagai masukan 
untuk pengambilan keputusan (Sudjana, 2000, p.267). Adapun program merupakan kegiatan atau aktivitas yang dirancang untuk melaksanakan kebijakan dan dilaksanakan untuk waktu yang tidak terbatas (Wirawan, 2011, p.17).

Evaluasi program adalah metode sistematik untuk mengumpulkan, menganalisis, dan memaknai informasi untuk menjawab pertanyaan dasar mengenai program (Wirawan, 2011, p.17).

Manfaat penelitian secara akademik memberikan informasi tentang implementasi dan kualitas team teaching di desa sasaran program PPAUD Kabupaten Kulon Progo dan sebagai informasi dalam keragaman model team teaching.

\section{METODE}

\section{Jenis Penelitian}

Penelitian ini merupakan penelitian evaluasi dengan logic models. Logic model merupakan pendekatan multi-evaluation. Logic model mendekati jenis evaluasi sistem analisis. Logic models have developed as an extension of objectives-oriented evaluation and are designed to fill in those steps between the program and its objectives (Fitzpatrick e t al, 2011, p.159). Pendekatan logic models merupakan perkembangan sebagai perluasan evaluasi berorientasi tujuan dan didesain untuk mengevaluasi antara pelaksanaan program dan tujuan program. Adapun pengertian dari logic model adalah "a tool that has been used by program managers and evaluators to describe the effectiveness of their programs" (McClawley, 2002, p.1).

\section{Waktu dan Tempat Penelitian}

Penelitian dilaksanakan di Kabupaten Kulon Progo dengan waktu penelitian dimulai pada bulan Januari sampai dengan bulan Mei 2013.

\section{Subjek Penelitian}

Subjek penelitian adalah 80 pendidik dengan sampel 65 orang dan dilakukan pengamatan pada tiga lembaga penyelenggara program PPAUD TPK yaitu TPK Fitrahsariı, TPK Al Hidayah, dan TPK Tunas Harapan. Jumlah sampel ditentukan berdasarkan Tabel Isaak dengan tingkat kesa- lahan 5\% dari jumlah populasi 80 adalah 65 orang (Wirawan, 2011, p.323). Penentuan kriteria didasarkan pada data monitoring dan evaluasi. Kemudian untuk subjek lembaga, ditentukan berdasarkan kriteria lembaga baik, sedang, dan kurang.

\section{Prosedur}

Penelitian ini menggunakan merupakan penelitian evaluasi dengan pendekatan kualitatif dan kuantitatif. Penelitian dilakukan dengan melakukan evaluasi kepada pendidik dengan memberikan kuesioner dan pengamatan serta wawancara mendalam ke tiga lembaga.

\section{Data, Instrumen, dan Teknik Pengum- pulan Data}

Instrumen penelitian yang digunakan untuk pengumpulan data adalah lembar kuesioner untuk pendidik, lembar observasi dan pedoman wawancara. Teknik pengumpulan data dilakukan dengan studi dokumen, kuesioner, observasi dan wawancara. Teknik analisis data yang dilakukan analisis deskriptif.

Pengumpulan data dilakukan dengan studi dokumen, observasi, wawancara, dan memberikan daftar pertanyaan atau angket yang sudah tervalidasi dan reliabel. Validitas yang digunakan dalam penelitian ini adalah validitas isi. Perolehan validitas isi memerlukan dua aspek penting yaitu valid isi dan valid teknik sampling. Validitas isi dilakukan dengan mencermati butirbutir instrumen berdasarkan kisi-kisi. Butirbutir instrumen tersebut kemudian dikonsultasikan kepada pembimbing dan dimintakan pendapat dan divalidasi dari ahli bidang penelitian dan evaluasi pendidikan.

Studi dokumen dilakukan dalam penggambaran awal kondisi pendidik. Observasi dilakukan untuk memperoleh data tentang keberadaan fasilitas sarana dan prasarana serta pemanfaatannya oleh pendidik. Observasi juga dilakukan terhadap peserta didik, bagaimana suasana pembelajaran dan reaksi anak-anak terhadap kegiatan tersebut. Wawancara dilakukan kepada orangtua dan pengelola lembaga. Wawancara dilakukan untuk mengetahui hal-hal di luar pendidik yang berhubungan 
dengan pelaksanaan kegiatan pembelajaran dan kerja sama antar pendidik. Adapun angket diberikan kepada pendidik program PPAUD. Teknis pelaksanaan dilakukan dengan kunjungan lapangan langsung ke titik layanan yang menjadi sampel penelitian.

\section{Teknik Analisis Data}

Data dari penelitian ini berupa jawaban atas kuesioner berupa angka yang dianalisis dengan persentase dan data berpa hasil wawancara dan pengamatan yang dianalisis secara induktif dengan pendekatan kualitatif.

Data hasil kuesioner terdiri dari empat aspek yaitu aspek pemahaman, perencanaan, pelaksanaan, dan evaluasi team teaching. Data hasil jawaban kuesioner dihitung sesuai pedoman perhitungan pada masing-masing aspek dan dicocokkan dengan tabel keefektifan tanpa pertimbangan untuk diketahui efektif dan tidaknya aspek tersebut. sebagai berikut:

Perhitungan tiap komponen adalah

Perhitungan Keefektifan Pemahaman Pendidik Tentang Team Teaching

Komponen pemahaman team teaching pendidik terdiri atas lima butir pertanyaan. Bobot nilai komponen pemahaman adalah 1,7. Rincian bobot nilai dan penafsiran dalam tabel 1 berikut:

Tabel 1. Perhitungan Komponen Pemahaman

\begin{tabular}{|c|c|c|c|}
\hline Jawaban & Nilai & Kategori & Ket \\
\hline $4-5$ & $1,38-1,70$ & $81 \%-100 \%$ & $\begin{array}{c}\text { Level A } \\
\text { (sangat } \\
\text { efektif) }\end{array}$ \\
\hline $3-4$ & $1,04-1,36$ & $61 \%-80 \%$ & $\begin{array}{c}\text { Level B } \\
\text { (efektif) }\end{array}$ \\
\hline $2-3$ & $0,70-1,02$ & $41 \%-60 \%$ & $\begin{array}{c}\text { Level C } \\
\text { (cukup) }\end{array}$ \\
\hline $1-2$ & $0,36-0,68$ & $21 \%-40 \%$ & $\begin{array}{c}\text { Level D } \\
\text { (kurang } \\
\text { efektif) }\end{array}$ \\
\hline$<1$ & $<0,34$ & $<21 \%$ & $\begin{array}{c}\text { Level E ( } \\
\text { sangat } \\
\text { kurang } \\
\text { efektif) }\end{array}$ \\
\hline
\end{tabular}

Perhitungan Keefektifan Perencanaan Team Teaching Pendidik

Komponen perencanaan team teaching pendidik terdiri atas sembilan butir pertanyaan. Bobot nilai komponen perencanaan adalah 3,oo. Rincian bobot nilai dan penafsiran dalam tabel 2 berikut:

Tabel 2. Perhitungan Komponen Perencanaan

\begin{tabular}{|c|c|c|c|}
\hline Jawaban & Nilai & Kategori & Ket \\
\hline 7-9 & $2,43-3,00$ & $81 \%-100 \%$ & $\begin{array}{l}\text { Level A } \\
\text { (sangat } \\
\text { efektif) }\end{array}$ \\
\hline $5-7$ & $1,83-2,40$ & $61 \%-80 \%$ & $\begin{array}{l}\text { Level B } \\
\text { (efektif) }\end{array}$ \\
\hline $4-5$ & $1,23-1,80$ & $41 \%-60 \%$ & $\begin{array}{l}\text { Level C } \\
\text { (cukup) }\end{array}$ \\
\hline $2-4$ & $0,63-1,20$ & $21 \%-40 \%$ & $\begin{array}{l}\text { Level D } \\
\text { (kurang } \\
\text { efektif) }\end{array}$ \\
\hline$<2$ & $<0,6$ & $<21 \%$ & $\begin{array}{l}\text { Level E } \\
\text { (sangat } \\
\text { kurang } \\
\text { efektif) }\end{array}$ \\
\hline
\end{tabular}

Perhitungan Keefektifan Pelaksanaan Team Teaching Pendidik

Komponen pelaksanaan team teaching pendidik terdiri atas sembilan butir pertanyaan. Bobot nilai komponen pelaksanaan adalah 3,oo. Rincian bobot nilai dan penafsiran dalam tabel 3 berikut:

Tabel 3. Perhitungan Komponen Pelaksanaan

\begin{tabular}{|c|c|c|c|}
\hline Jawaban & Nilai & Kategori & Ket \\
\hline $7-9$ & $2,43-3,00$ & $81 \%-100 \%$ & $\begin{array}{c}\text { Level A } \\
\text { (sangat } \\
\text { efektif) }\end{array}$ \\
\hline $5-7$ & $1,83^{-2,40}$ & $61 \%-80 \%$ & $\begin{array}{l}\text { Level B } \\
\text { (efektif) }\end{array}$ \\
\hline $4-5$ & $1,23-1,80$ & $41 \%-60 \%$ & $\begin{array}{l}\text { Level C } \\
\text { (cukup) }\end{array}$ \\
\hline $2-4$ & $0,63-1,20$ & $21 \%-40 \%$ & $\begin{array}{c}\text { Level D } \\
\text { (kurang } \\
\text { efektif) }\end{array}$ \\
\hline$<2$ & $<0,6$ & $<21 \%$ & $\begin{array}{l}\text { Level E } \\
\text { (sangat } \\
\text { kurang } \\
\text { efektif) }\end{array}$ \\
\hline
\end{tabular}

Perhitungan Keefektifan Evaluasi Team Teaching Pendidik

Komponen evaluasi team teaching pendidik terdiri atas tujuh butir pertanyaan. 
Bobot nilai komponen evaluasi adalah 2,30. Rincian bobot nilai dan penafsiran dalam tabel 4 berikut:

Tabel 4. Perhitungan Komponen Evaluasi

\begin{tabular}{|c|c|c|c|}
\hline Jawaban & Nilai & Kategori & Ket \\
\hline $6-7$ & $1,86-2,30$ & $81 \%-100 \%$ & $\begin{array}{c}\text { Level A } \\
\text { (sangat } \\
\text { efektif) }\end{array}$ \\
\hline $4-6$ & $1,40-1,84$ & $61 \%-80 \%$ & $\begin{array}{l}\text { Level B } \\
\text { (efektif) }\end{array}$ \\
\hline $3-4$ & $0,94^{-1,38}$ & $41 \%-60 \%$ & $\begin{array}{l}\text { Level C } \\
\text { (cukup) }\end{array}$ \\
\hline $1-3$ & $0,48-0,92$ & $21 \%-40 \%$ & $\begin{array}{c}\text { Level D } \\
\text { (kurang } \\
\text { efektif) }\end{array}$ \\
\hline$<1$ & $<0,46$ & $<21 \%$ & $\begin{array}{l}\text { Level E } \\
\text { (sangat } \\
\text { kurang } \\
\text { efektif) }\end{array}$ \\
\hline
\end{tabular}

Data hasil wawancara dan pengamatan merupakan data hasil pelaksanaan team teaching dan faktor yang menjadi pendukung dan penghambat team teaching. Data direduksi dan di display, ditafsirkan, disimpulkan dan dinarasikan.

\section{HASIL PENELITIAN DAN PEMBAHASAN}

Pemahaman pendidik terhadap team teaching sudah baik. Hal ini berdasarkan pada data hasil kuesioner yang diberikan kepada pendidik yaitu pada pertanyaan tentang pemahaman sejumlah 5 butir, dengan skor maksimal 1,7 dengan jumlah responden 65 diperoleh data sebagai berikut:

Tabel 5. Skor Keefektifan Pemahaman

\begin{tabular}{ccccc}
\hline No Komponen & $\begin{array}{c}\text { Rata- } \\
\text { rata } \\
\text { skor }\end{array}$ & Kategori & Ket \\
\hline \multirow{1}{*}{1} & Pemahaman & 1,52 & $81 \%-100 \%$ & Sangat \\
& & & Efektif \\
\hline
\end{tabular}

Dari hasil perhitungan dapat pendidik dimaknai memahami tentang team teaching. Pemahaman pendidik dalam team teaching sangat efektif.

Komponen pemahaman meliputi daya tanggap terhadap tugas pokok dan tanggung jawab, kemampuan menerima mitra, dan kemampuan kerja sama.

Perencanaan team teaching meliputi unsur keberadaan jadwal, penghargaan atas proses dibandingkan hasil dalam perencanaan tersebut, kemunculan ide, mekanisme penerimaan ide, pewujudan ide dalam kegiatan, keterlibatan pendidik dalam membuat perencanaan untuk semua anak, keterlaksanaan rencana, pembuatan rencana yang memberikan kesempatan bermain anak dan kemunculan bahasa inklusif. Data hasil kuesioner yang diberikan kepada pendidik yaitu pada pertanyaan tentang perencanaan sejumlah 9 butir, dengan skor maksimal 3,0 dengan jumlah responden 65 diperoleh data sebagai berikut:

Tabel 6. Skor Keefektifan Perencanaan

\begin{tabular}{ccccc}
\hline No & Komponen & $\begin{array}{c}\text { Rata- } \\
\text { rata } \\
\text { skor }\end{array}$ & Kategori & Ket \\
\hline \multirow{1}{*}{1} & Perencanaan & 2,79 & $81 \%-100 \%$ & $\begin{array}{c}\text { Sangat } \\
\text { Efektif }\end{array}$ \\
\hline
\end{tabular}

Pelaksanaan team teaching pendidik program PPAUD meliputi sub komponen terdengarnya suara setiap pendidik oleh peserta didik, perbedaan suasana pembelajaran ketika dilakukan dengan tim dan sendiri, variasi pembelajaran, dilakukannya pengamatan kepada peserta didik selama kegiatan, kemunculan usulan pendidik kepada tim pendidik selama kegiatan berlangsung, pemanfaatan media dan sarana prasarana, pendidik memberikan kontak dan perhatian kepada siswa, respon peserta didik terhadap pendidik, dan adanya bahasa inklusif.

Skor hasil perhitungan terhadap komponen pelaksanaan mendapatkan hasil 2,91 dari skor maksimal 3, dan jika dipersentasekan adalah 97,1\% dan termasuk dalam level A dengan keterangan sangat efektif.

Tabel 7. Skor Keefektifan Pelaksanaan

\begin{tabular}{llccc}
\hline No & Komponen & $\begin{array}{c}\text { Rata- } \\
\text { rata } \\
\text { skor }\end{array}$ & Kategori & Ket \\
\hline \multirow{1}{*}{1} & Pelaksanaan & 2,91 & $81 \%-100 \%$ & Sangat \\
& & & Efektif
\end{tabular}

Evaluasi team teaching meliputi sub komponen ketersediaan waktu untuk membicarakan proses pembelajaran, adanya 
proses penyelesaian masalah, permasalahan dalam tim dapat terselesaikan dengan baik dalam suasana yang hangat, adanya musyawarah mufakat yang dilakukan dalam penyelesaian masalah, terjaganya kerahasiaan masalah, dilakukannya perencanaan pembelajaran untuk pendidikan yang lebih baik dan perencanaan didasarkan pada hasil pelaksanaan kegiatan sebelumnya.

Perolehan skor hasil perhitungan terhadap komponen evaluasi team teaching pendidik PAUD adalah sangat efektif dengan rincian sebagai berikut:

Tabel 8. Skor Keefektifan Evaluasi

\begin{tabular}{ccccc}
\hline No & Komponen & $\begin{array}{c}\text { Rata- } \\
\text { rata } \\
\text { skor }\end{array}$ & Kategori & Ket \\
\hline & Evaluasi & 2,28 & $81 \%-100 \%$ & $\begin{array}{c}\text { Sangat } \\
\text { Efektif }\end{array}$ \\
\hline
\end{tabular}

Skor hasil perhitungan terhadap komponen pelaksanaan mendapatkan hasil 2,28 dari skor maksimal 2,3 dan jika dipersentasekan adalah 99,3\% dan termasuk dalam level A dengan keterangan sangat efektif. Keterangan sangat efektif ini dimaknai bahwa kegiatan evaluasi yang dilakukan oleh tim pendidik bermanfaat untuk proses yang telah dilakukan maupun untuk perencanaan kegiatan yang akan datang.

\section{Hasil Team Teaching di TPK Fitrahsari 1/ KB Kresna Cekelan}

TPK Fitrahsari beralamat di Dusun Cekelan, Desa Karangsari, Kecamatan Pengasih. TPK Fitrahsari merupakan lembaga bentukan baru dari program PPAUD. Jangkauan TPK Fitrahsari 1 meliputi 6 dusun yaitu: Dusun Dukuh, Dusun Cekelan, Dusun Josutan, Dusun Gunungpentul, Dusun Kopat dan Dusun Sendang. Lembaga ini mulai beroperasional tanggal 17 Oktober tahun 2009.

Kegiatan TPK Fitrahsari 1 terpusat di Dusun Cekelan. Fasilitas gedung belum ada, kegiatan menggunakan rumah kepala Dusun. Pembangunan gedung sedang dalam proses, dari dana program PNPM yang akan selesai tahun 2013 ini. Jumlah ruang belajar adalah 1 ruang indoor dengan beberapa APE dalam yang terbatas secara jumlah maupun variasinya. Ruang indoor ini disekat menjadi dua ketika pembelajaran. Ruang untuk pembelajaran lainnya adalah 1 ruang di teras dan halaman outdoor dengan beberapa APE luar. Terdapat pula ruang tunggu orangtua (pengantar) di sebelah barat ruang utama. Fasilitas lain yang ada adalah sarana cuci tangan dengan air mengalir dan toilet.

TPK Fitrahsari 1 dikelola oleh 3 orang pengelola dan diampu kegiatan pelayanannya oleh 3 orang pendidik. Kegiatan pembelajaran dilakukan pada hari Senin, Selasa, Rabu, dan Kamis. Kegiatan bersama dilakukan pada hari Kamis dan kegiatan berdasarkan kelompok (sentra) dilakukan pada hari Senin sampai Rabu.

Pasca program PPAUD TPK Fitrahsari mengajukan izin operasional ke Dinas Pendidikan dan mempunyai nama Kelompok Bermain Kresna Cekelan. Biaya pendidikan di KB Kresna Cekelan sebesar Rp5.00o,- tiap bulan untuk setiap anak.

Berdasarkan data hasil wawancara orangtua peserta didik merasa puas dengan layanan PAUD anak-anak mereka. Sebagaimana diungkapkan oleh salah satu dari orangtua sebagai berikut:

“...iya, bagus, bu gurunya sama anak-anak sabar, mengajarnya sabar, gurunya juga akur satu sama lainnya.

...bagus, bagusnya bocah bisa nangkap. Disamping itu kegiatan yang diberikan mudah untuk anak"

Orangtua mengatakan banyak kemajuan yang dicapai oleh anak-anak mereka. Kemajuan tersebut dalam hal anak terbiasa untuk belajar di rumah, menikmati waktu luang mereka dengan kegiatan mewarnai dan bermain bahan limbah untuk alat permainan yang mengasyikan bagi mereka.

Kegiatan team teaching pendidik dipandang baik oleh orangtua. Pendidik saling menghargai satu sama lain, saling bekerja sama dalam setiap kegiatan dan jarang sekali bahkan tidak pernah berselisih pendapat di depan wali. Pendidik memberikan perhatian kepada setiap peserta didik dengan baik. Orangtua sering tersentuh 
dengan perhatian pendidik terhadap peserta didik.

Pengelola KB Kresna Cekelan merasa puas dengan team teaching yang dilakukan pendidik di lembaganya. Pendidik selalu dapat bekerja sama dengan baik dalam pengelolaan kegiatan di lembaga tersebut. Pendidik mengelola kegiatan pemberian makanan tambahan, komunikasi dengan wali terkait pengumunan-pengumuman dan pengelolaan kegiatan pembelajaran mulai dari kegiatan perencanaan, pelaksanaan, dan evaluasi kegiatan senantiasa dilakukan dengan bekerja sama dan baik. Kegiatan di luar lembaga juga dapat dilaksanakan dengan baik seperti kegiatan pertemuan himpaudi, kegiatan pertemuan tingkat gugus dan kegiatan luar yang lain.

Pendidik sejumlah tiga orang di KB Kresna Cekelan diakui hebat oleh pengelola lembaga, sebagaimana yang disampaikan pengelola sebagai berikut:

"Walah Mbak, kalau saya sudah berterima kasih mereka sudah mau mengajar itu, lha bagi saya mereka itu hebat, wong bayarnya tidak cukup untuk beli sabun, apalagi tanggungjawab mereka besar, mendidik anak orang lain, bagi saya mereka itu luar biasa Mbak. Kadangkadang saya terenyuh dengan balas jasa yang diterima mereka, tapi ya mau bagaimana lagi lha wong memang belum ada sumber dana yang layak untuk membayar mereka, ke depan semoga ada perhatian dari Dinas, dan semoga lembaga kami ke depan dapat menggali sumber dana sehingga dapat membayar layak mereka."

Tanggung jawab yang besar dan honor yang sedemikian kecil membuat pengelola "terenyuh" dengan kondisi pendidik. Pengelola belum mampu mencarikan honor yang layak untuk pendidik.

\section{Hasil Team Teaching di TPK Tunas Harapan/KB Pandawa Lima}

TPK Tunas Harapan beralamat di Dusun Karangpatihan, Desa Demangrejo, Kecamatan Sentolo. TPK Tunas Harapan mulai memberikan layanan PAUD kepada masyarakat pada November 2009 bersama dengan mulai berjalannya program PPAUD.

TPK Tunas Harapan mempunyai fasilitas berupa satu unit gedung dari program PNPM. Gedung tersebut dibangun pada tahun 2011. Pembagian ruang dalam gedung terbagi menjadi dua sekat utama, 1 ruang untuk kegiatan pembelajaran, satu ruang untuk kantor pendidik dan toilet. Ruang utama untuk kegiatan pembelajaran disekat secara tidak permanen menjadi dua ruangan untuk memisahkan kelompok anak. Ruang tunggu orangtua (pengantar) berada di teras ruangan.

TPK Tunas Harapan dikelola oleh 3 pengelola dan 4 orang pendidik. Kegiatan pembelajaran dilaksanakan pada hari Senin, Selasa, Rabu dan Kamis jam o8.oo WIB sampai dengan 10.30 WIB.

Pasca program PPAUD TPK Tunas Harapan mengajukan izin operasional ke Dinas Pendidikan dan mempunyai nama Kelompok Bermain Pandawa Lima. Biaya pendidikan di KB Pandawa Lima sebesar Rp. 10.00o,- tiap bulan untuk setiap anak.

Berdasarkan data hasil wawancara, orangtua mengikutsertakan anak mereka di KB Pandawa Lima dengan pertimbangan kedekatan lembaga dengan tempat tinggal mereka. Orangtua merasa mudah mengantarkan anak mereka karena jarak lembaga dengan rumah mereka dapat dijangkau dengan berjalan kaki. Berikut ungkapan dari orangtua:

“...ya karena PAUD ini yang terdekat, di sekitar sini tidak ada Paud Mbak, jadi Paud ini merupakan satu-satunya pilihan."

Pertimbangan lain orangtua mengikutsertakan anak mereka di KB Pandawa Lima adalah biaya yang terjangkau oleh mereka. Sebagian besar penduduk di sekitar lembaga merupakan penduduk dengan tingkat kesejahteraan menengah ke bawah, sehingga untuk kebutuhan hidup mereka sangat terbatas pemenuhannya. Kesadaran orangtua akan pentingnya PAUD belum diikuti kemampuan mereka untuk membayar biaya pendidikan bagi anaknya.

Kepuasan orangtua terhadap pelayanan yang diberikan kepada anak mereka 
cukup tinggi. Orangtua menghargai pendidik yang telah mendidik anak-anak mereka. Imbalan yang tidak sebanding dalam bahasa mereka. Kerja sama pendidik dalam persepsi orangtua berjalan dengan baik. Pendidik bekerja sama dalam mengelola kegiatan dan terlihat akur, belum pernah ditemui orangtua pendidik berselisih paham. Pendidik juga memberikan perhatian yang luar biasa kepada anak-anak. Pendidik membiasakan budaya antri, disiplin dan mendengarkan cerita anak.

Menurut pengelola KB Pandawa Lima, pengelolaan PAUD sudah baik. Tim pendidik lembaga tersebut merupakan pendidik yang telah dilatih dengan materi yang sesuai untuk Pendidikan Anak Usia Dini dan telah berpengalaman melakukan kegiatan pembelajaran selama tiga tahun.

Kerja sama yang dibangun antara pendidik satu dengan yang lain mendapatkan apresiasi dari pengelola. Pengelola melihat kerja sama mereka sangat baik, mereka dapat saling mendukung dan saling menguatkan satu sama lain.

Konflik antar pendidik tidak menimbulkan gejolak yang berarti bagi keutuhan kerja sama mereka. Konflik yang timbul biasanya seputar kekosongan pendidik jika ada salah satu yang absen karena agenda keluarga. Jika hal ini terjadi maka pengelola dan tim pendidik akan melakukan koordinasi terkait pengelolaan kegiatan.

TPK Tunas Harapan mendapatkan izin operasional dari Dinas Pendidikan Kabupaten Kulon Progo dengan nomor 108 tahun 2013 tertanggal 18 April 2013 dengan nama Kelompok Bermain Pandawa Lima.

Kondisi peserta didik di TPK Tunas Harapan atau KB Pandawa Lima terlihat sangat enjoy dalam mengikuti kegiatan. Peserta didik dibagi ke dalam dua kelompok usia dengan masing-masing kelompok diampu oleh dua orang pendidik.

Pemanfaatan sarana dan prasarana serta media fisik dilakukan dengan baik. Ruang kegiatan berada di dalam dan untuk bermain bebas mempunyai halaman yang luas di luar gedung. Alat Permainan Edukatif Dalam (APE dalam) diletakkan di rakrak mainan dan digunakan jika tema sesuai. Adapun APE luar digunakan oleh peserta didik pada waktu istirahat dan sela-sela kegiatan yang lain. Pemanfaatan sarana cuci tangan juga dilakukan dengan baik. Pada setiap hari sewaktu jam makan, peserta didik diberikan waktu untuk secara antri melakukan cuci tangan di tempat cuci tangan di sebelah barat gedung PAUD.

Peserta didik dalam setiap kegiatan didampingi oleh tim pendidik. Kegiatan makan bersama dilakukan di kelas besar dan antara kelas besar dan kelas kecil digabungkan menjadi satu pun demikian pendidiknya. Satu orang pendidik memimpin di depan dan tiga orang pendidik yang lain mengkondisikan peserta didik di belakang.

Peserta didik di KB Pandawa Lima sejumlah 52 anak, dikelompokkan menjadi dua kelas. Kelompok dengan usia anak 1,5 tahun sampai 3 tahun sejumlah 19 anak dan kelompok anak dengan usia 3 sampai 5 tahun sejumlah 33 anak.

Peserta didik selama mengikuti kegiatan PAUD terlibat aktif dan menikmati semua kegiatan. Pendidik yang di belakang mengkondisikan peserta didik dan membantu kesulitan atau ketidakpahaman peserta didik ketika salah seorang pendidik berada di depan. Peserta didik dapat secara interaktif berkomunikasi dan mengikuti semua kegiatan dengan gembira.

\section{Hasil Team Teaching di TPK Al Hidayah/ KB Al Hidayah}

TPK Al Hidayah beralamat di Dusun VIII, Desa Krembangan, Kecamatan Panjatan. TPK Al Hidayah mulai memberikan layanan PAUD kepada masyarakat pada November 2009 bersama dengan mulai berjalannya program PPAUD.

TPK Al Hidayah mempunyai fasilitas berupa satu unit gedung dari bekas SD Krembangan. Gedung tersebut mempunyai tiga ruang yang masih layak pakai. Pembagian ruang dalam gedung terbagi menjadi dua sekat utama, 1 ruang yang merupakan gabungan dua kelas dipakai untuk kegiatan pembelajaran dan penyimpanan APE dalam serta buku administrasi PAUD. Ruang lain di sebelah timur seluas satu kelas digunakan untuk menyimpan APE luar dan toilet. Halaman depan gedung dipakai untuk kegiatan outdoor dan senam. Gedung TPK Al Hida- 
yah bersebelahan dengan gedung Polindes. Adapun ruang tunggu orangtua (pengantar) berada di teras ruangan.

TPK Al Hidayah dikelola oleh 3 pengelola dan 4 orang pendidik. Kegiatan pembelajaran dilaksanakan pada hari Senin, Selasa, Rabu dan Jumat jam o8.oo WIB sampai dengan 10.30 WIB.

Pasca program PPAUD TPK Al Hidayah mengajukan izin operasional ke Dinas Pendidikan dan mempunyai nama Kelompok Bermain Al Hidayah. Izin operasional KB Al Hidayah masih dalam proses verifikasi Dinas Pendidikan. Biaya pendidikan di KB Al Hidayah sebesar Rp. 10.000,- tiap bulan untuk setiap anak.

Berdasarkan data hasil wawancara orangtua peserta didik merasa puas dengan layanan PAUD anak-anak mereka. Orangtua mengatakan banyak kemajuan yang dicapai oleh anak-anak mereka. Kemajuan tersebut dalam hal anak terbiasa untuk belajar berdo'a, bernyanyi, kemandirian, dan disiplin.

Kerja sama pendidik dipandang baik oleh orangtua. Pendidik saling menghargai satu sama lain, saling bekerja sama dalam setiap kegiatan dan tidak pernah berselisih pendapat di depan wali. Pendidik memberikan perhatian kepada peserta didik dengan baik.

Keluhan orangtua lebih kepada pemanfaatan sarana dan keamanan tempat belajar. Gedung yang merupakan bekas SD dan berupa bangunan lama membuat orang tua khawatir akan keamanannya. Banyaknya sarang lebah memberikan kekhawatiran dan ketakutan orangtua karena salah satu anak pernah tersengat lebah. Penjagaan lingkungan main dinilai kurang oleh orangtua, hal ini sehubungan dengan pemanfaatan halaman samping untuk senam tetapi lebih sering digunakan untuk menjemur padi dan menyisakan kotoran yang dapat membuat anak tidak nyaman.

Orangtua juga berharap adanya perhatian yang layak dari Dinas Pendidikan atau Pemerintah Daerah Kabupaten Kulon Progo untuk pendidik PAUD. Sebagaimana diungkap oleh salah satu narasumber sebagai berikut:
"Mbok ya ada perhatian untuk guru disini, ibaratnya untuk beli sabun saja tidak cukup apalagi untuk menghargai kerja mereka. Kami wali sudah berkontribusi sesuai dengan kemampuan kami dan sudah selayaknya Dinas juga memperhatikan, jangan seperti koperasi, disuruh hidup sendiri tanpa ada perhatian, lha dulu yang punya program siapa?"

Pengelola KB Al Hidayah melihat kerja sama yang dilakukan pendidik sebagai hal yang sangat baik. Pendidik dapat saling bertenggang rasa dalam menunaikan tugasnya. Pendidik mampu membuat kedekatan antara lembaga dengan masyarakat dan wali anak usia dini semakin erat.

Pendidik juga yang memunyai inisiatif perlunya penjaringan kemampuan wali untuk membayar biaya pendidikan anak mereka. Penjaringan dilakukan dengan menyebar lembaran kesanggupan pembiayaan kepada tiap-tiap wali. Hasilnya di luar perkiraan, wali sanggup membayar dengan nominal minimal $\mathrm{Rp}$ 10.000,- sebagaimana diungkapkan pengelola sebagai berikut:

"Pendidik di KB Al Hidayah juga memunyai inisiatif yang menurut saya luar biasa, mereka melakukan penggalian dana, lebih tepatnya penggalian kemampuan membayar para orangtua anak. Pendidik menulis angket yang kemudian diisi oleh orangtua yang isinya lembar pertanyaan tersebut seputar kegiatan pembelajaran dan kemampuan orangtua dalam membayar. Hasil dari angket yang disebarkan sangat membantu pengelola dalam menentukan biaya pendidikan di lembaga ini."

Kegiatan pembelajaran dan pelayanan PAUD seperti Bina Keluarga Balita (BKB) dan penyuluhan diinisiasi pula oleh pendidik. Pendidik dapat bekerja sama dengan baik dalam perencanaan, pelaksanaan, dan evaluasi kegiatan layanan PAUD di KB AL Hidayah.

Konflik yang pernah muncul dapat terselesaikan dengan baik diantara ketiga pendidik. Konflik yang muncul lebih kepada masalah personal yang tidak ada kaitannya 
dengan pekerjaan memberikan layanan di PAUD.

TPK Al Hidayah mengajukan izin operasional pasca program PPAUD berakhir di bulan Desember 2012 dengan nama Kelompok Bermain Al Hidayah, dan masih dalam tahap verifikasi izin operasional.

Kelompok Bermain Al Hidayah mempunyai peserta didik 59 anak. Peserta didik ini dikelompokkan menjadi tiga. Kelompok dengan usia anak 2-3 tahun sejumlah 28 anak. Kelompok dengan usia anak 3-4 tahun sejumlah 18 anak. Kelompok dengan usia anak 4-5 tahun sejumlah 13 anak.

Setiap kelompok diampu oleh satu orang pendidik. Pelaksanaan team teaching dilakukan setiap hari senin, sedangkan hari Selasa, Rabu dan Jumat masing-masing pendidik mengampu kelas mereka sendirisendiri. Kegiatan bersama diisi kegiatan baik dalam ruangan maupun kegiatan luar ruangan.

Berdasarkan pengamatan yang dilakukan, suasana pembelajaran interaktif. Pemanfaatan ruang dan sarana fisik serta media cukup baik. Alat permainan edukatif baik dalam maupun luar termanfaatkan dengan baik pula. Penggunaan alat permainan edukatif dalam disesuaikan dengan tema kegiatan pada hari itu. Adapun penggunaan alat permainan edukatif luar digunakan setiap sesi istirahat ataupun sesi sebelum kegiatan inti dimulai.

Adapun berdasarkan wawancara dengan orangtua dan wali anak orangtua dan wali menyatakan bahwa melalui PAUD anak-anak menjadi tambah berani. Pendapat tersebut diungkapkan oleh salah satu orangtua sebagai berikut:

".. Anak lebih pemberani, hafalan lumayan (doa, nyanyian), mau memperhatikan."

\section{Faktor Pendukung dan Penghambat Team Teaching}

Berdasarkan catatan keterangan data dari kuesioner dan dari pengamatan serta wawancara yang dilakukan terdapat beberapa faktor yang menjadi pendukung team teaching sebagai berikut: (1). Imbangan atau rasio jumlah peserta didik dan jumlah pen- didik dalam satu lembaga.Rasio pendidik dan anak yang seimbang akan menjadi pendukung terlaksanakannya team teaching. (2) Ketersediaan sarana dan prasarana di lembaga. Sarana dan prasarana yang memadai dan lengkap akan memudahkan berlangsungnya team teaching. Tim pendidik dapat memanfaatkan sarana dan prasarana tersebut untuk mendukung kegiatan pembelajaran yang mereka lakukan. (3) Rekan pendidik yang terbuka dan mempunyai rasa kerja sama. Sikap mental diri pribadi pendidik yang merupakan bagian dari tim menjadi pendukung terhadap team teaching. Pendidik yang mempunyai sikap terbuka, mudah diajak kerja sama, dan memunyai keinginan maju yang besar akan menjadi pendukung dalam terlaksanakannya team teaching yang baik. (4) Ketercapaian tumbuh kembang anak yang optimal. Melalui team teaching setiap anak akan mendapatkan perhatian yang lebih baik dari pendidik, ketika satu orang pendidik menjelaskan kegiatan di depan, pendidik yang di belakang akan dapat mendampingi anak. Tim pendidik dapat memberikan perhatian dan kontak selama kegiatan berlangsung dan anak akan terfasilitasi dengan lebih baik. (5) Proses administrasi yang lebih memudahkan dan lebih lengkap. Kegiatan team teaching melibatkan seluruh pendidik dalam setiap tahapan pembelajaran. Hal ini akan memudahkan proses pengadministrasian dan membuat administrasi yang dibuat lebih lengkap dibandingkan pendidik melakukannya secara solo. (6) Bertambahnya kemampuan pendidik karena interaksi dan kerja sama yang mereka bangun.

Hal yang menjadi penghambat team teaching adalah sebagai berikut: (1) Jumlah pendidik sedikit jadi tidak memungkinkan di bagi ke dalam beberapa tim pendidik. (2) Fasilitas atau sarana prasarana yang terbatas. Jumlah ruang pembelajaran yang hanya satu, dengan jumlah anak banyak dengan ragam usia mereka dan pendidik sedikit akan menjadi penghambat terlaksanakannya team teaching. 


\section{Pembahasan}

Keefektifan Pemahaman Team Teaching

Pemahaman pendidik terhadap team teaching meliputi komponen daya tanggap terhadap tugas pokok dan tanggung jawab, kemampuan menerima mitra, kemampuan kerja sama, kemampuan memetakan anak. Daya tanggap terhadap tugas pokok dan tanggung jawab pendidik program PPAUD sebagian besar sudah memahami dengan baik. Berdasarkan data dari instrumen penelitian tidak ada alasan khusus yang menjadi sebab pendidik tidak memahami tugas pokok dan tanggung jawab mereka.

Sub komponen pemahaman tentang kemampuan menerima mitra atau merasa sukarela menjadi bagian dari tim pendidik secara umum baik, terdapat beberapa temuan terkait hal ini yaitu, pendidik merasa mau tidak mau menerima mitra mereka "karena mereka yang sudah dipilih oleh masyarakat" jadi mereka berupaya maksimal untuk dapat saling menerima dan menyesuaikan diri.

Sub komponen pelaksanaan pembelajaran bersama dimasukkan dalam jadwal pelajaran mendapatkan respon baik. Semua pendidik yang menjadi sampel memasukkan pembelajaran bersama dalam jadwal mereka.

Subkomponen tim secara bersamasama tampil dalam kelas yang sama mendapatkan respon bervariasi. Hal ini disebabkan desain masing-masing pendidik terhadap kegiatan pembelajaran berbeda-beda. Berikut beberapa alasan pendidik tidak tampil secara bersama-sama dalam kelas yang sama; (1) usia anak dikelompokkan, satu kelompok diampu satu orang pendidik (2) lembaga ada 6 titik kegiatan masingmasing titik diampu pendidik yang bertanggung jawab dalam titik tersebut, (3) sudah ada satu orang pendidik yang bertanggung jawab dalam kelompok usia anak, (4) terbatasnya jumlah pendidik, (5) pendidik hanya tampil bersama ketika awal kegiatan dan akhir kegiatan.

Berdasarkan uraian di atas secara umum pendidik memahami tentang team teaching. Akan tetapi team teaching yang mereka lakukan bukan team teaching kategori A dimana dua orang pendidik atau tim pendidik mengampu kelas yang sama dalam waktu yang bersamaan dengan pembagian peran yang proporsional akan tetapi merupakan team teaching kategori B dalam istilah Goetz.

\section{Keefektifan Perencanaan Team Teaching}

Perencanaan team teaching pendidik meliputi komponen keberadaan jadwal, keterlibatan dalam perencanaan, kemunculan ide, mekanisme penerimaan ide dan kemunculan bahasa inklusif. Berdasarkan data dari kuesioner dapat disimpulkan bahwa perencanaan team teaching pendidik efektif.

Hal yang menjadi kendala dalam perencanaan pendidik adalah keterlaksanaan rencana sesuai dengan kegiatan. Kondisi ini disebabkan oleh beberapa hal diantaranya; (1) Melihat situasi yang ada, dimaksudkan ketika anak-anak tidak mood melakukan suatu kegiatan maka hal tersebut batal dilakukan (2) Cuaca yang berubah misal tiba-tiba hujan, sejatinya kegiatan outdoor menjadi berubah kegiatan indoor, (3) Kesibukan pendidik menjadi hambatan direalisasikannya suatu rencana, kondisi yang memunculkan situasi tersebut missalnya ada kegiatan masyarakat, undangan lain, dan rapat sehingga pendidik harus meninggalkan kegiatan.

Perencanaan di beberapa lembaga dilakukan secara perwakilan saja. Pendidik melakukan perencanaan untuk usia tertentu tanpa ada komunikasi dengan pendidik di kelompok usia yang lain. Hal ini tidak baik, karena akan menimbulkan kemungkinan perbedaan alur dan kegiatan. Team teaching dalam komponen perencanaan melibatkan seluruh anggota tim dalam merencanakan kegiatan untuk semua usia anak. Perencanaan yang dilakukan sebagian-sebagian belum memenuhi komponen perencanaan dalam team teaching.

\section{Keefektifan Pelaksanaan Team Teaching}

Pelaksanaan team teaching pendidik meliputi komponen porsi mengajar, pembagian media dan materi, pemanfaatan fasilitas, dan adanya bahasa inklusif. 
Berdasarkan data dari kuesioner dapat disimpulkan bahwa pelaksanaan team teaching sangat efektif. Beberapa catatan terkait pelaksanaan team teaching adalah pelaksanaan pembelajaran yang variatif. Variasi kegiatan pembelajaran meliputi (1) Kegiatan menggunakan sentra (bahan alam, sentra persiapan, dan imtaq), (2) Pembelajaran dilakukan di dalam kelas, ada kalanya dilakukan di luar kelas seperti jalan-jalan, bermain air dsb, (3) Ada perpindahan sentra, ada pertukaran pendidik dan anak didik, dan (4) Pilihan permainan.

Selama kegiatan pembelajaran juga dilakukan pengamatan kepada peserta didik. Hal-hal yang menjadi fokus pengamatan adalah (1) Ketika berdoa ikut tidak, senam, melakukan kegiatan, bermain bebas, semua kegiatan anak selama pembelajaran, (2) Apakah anak sudah menguasai perkembangan atau belum, (3) Kemandirian dalam menjalankan tugas dan (4) Tingkah laku anak, perkembangan, hubungan antarteman dan emosinya.

Hal-hal di atas menjadi pendukung terlaksananya pelaksanaan team teaching dengan baik. Semua responden melakukan pembelajaran bervariasi dan melakukan pengamatan kepada peserta didik. Pembelajaran bervariasi meminimalkan kejenuhan peserta didik dalam mengikuti kegiatan. Variasi pembelajaran beragam mulai dari pergantian pendidik, pergantian arena permainan dan belajar, dan pergantian tema. Adapun pengamatan dilakukan pendidik kepada peserta didik dengan tujuan mendampingi kegiatan dan ketercapaian kemampuan peserta didik disamping mereka juga melakukan penilain melalui pengamatan tersebut.

Dari pengamatan yang dilakukan dalam pada tiga lembaga, 1 lembaga melaksanakan team teaching murni tipe A sesuai klasifikasi yang diberikan oleh Goetz, yaitu pendidik secara bersama-sama melakukan kegiatan pembelajaran. Satu orang menjadi guru utama dan satu orang pendidik yang lain sebagai guru pendamping, bertugas memberikan bantuan dan tambahan penjelasan kepada anak yang di belakang dan membutuhkan bantuan guru.
Adapun data 2 lembaga melakukan team teaching tipe A dalam saat-saat tertentu saja, sedangkan dalam jadwal kebanyakan team teaching tipe $\mathrm{B}$, dimana guru tidak secara bersama-sama tampil di kelas yang sama akan tetapi dalam beberapa hal seperti perencanaan dan evaluasi pendidik melakukannya secara bersama-sama.

\section{Keefektifan Evaluasi Team Teaching}

Evaluasi team teaching pendidik meliputi komponen keberadaan evaluasi, munculnya masalah, penyelesaian masalah, dan perencanaan lanjutan/tindak lanjut.

Berdasarkan data dari kuesioner dapat disimpulkan bahwa evaluasi team teaching pendidik efektif. Beberapa catatan terkait evaluasi team teaching adalah pelaksanaan evaluasi yang beragam yaitu (1) setelah pembelajaran berlangsung, (2) dalam rapat pengurus, (3) hari pas tidak ada pembelajaran, (4) sebelum pembelajaran, (5) satu minggu sekali, (6) pada waktu anak istirahat.

Evaluasi merupakan hal yang penting dilakukan. Idealnya evaluasi dapat dilakukan dalam kegiatan yang pasti, terjadwal, dan membahas hal-hal yang telah ditentukan sebelumnya. Melalui evaluasi pendidik dapat melakukan perbaikan untuk pengelolaan kegiatan layanan PAUD selanjutnya. Evaluasi juga dapat melihat keberhasilan pelaksanaan kegiatan yang telah dirancang dan respon peserta didik terhadap kegiatan serta ketercapaian tujuan kegiatan.

\section{Hasil Team Teaching}

Team teaching telah berjalan di lembaga bentukan program PPAUD. Team teaching memberikan efek yang efektif terhadap peserta didik, orangtua, pengelola, dan pendidik itu sendiri.

Peserta didik dapat menikmati suasana pembelajaran, dapat terstimulasi perkembangan dan pertumbuhannya dan dapat terkondisikan dengan baik. Peserta didik dapat belajar mengungkapkan keinginan dan bekerja sama sebagaimana yang pendidik lakukan.

Orangtua peserta didik juga mendapatkan efek positif dari team teaching yang dilakukan pendidik. Orangtua puas 
terhadap layanan PAUD yang diterima anak mereka. Team teaching yang dilakukan pendidik dapat memberikan keteladanan kepada peserta didik tentang cara berkerja sama, cara menghargai pendapat orang lain, cara mendengarkan pendapat orang lain. Team teaching juga membuat anak lebih mendapat perhatian serta dapat mengikuti kegiatan dengan lebih baik karena adanya guru yang membantu di belakang.

Team teaching yang dilakukan pendidik memudahkan pengelola dalam memeroleh tempat di masyarakat. Layanan PAUD yang penuh perhatian dan pembagian tugas yang jelas memberikan kepuasan kepada orangtua sehingga secara otomatis nama lembaga akan baik di mata masyarakat. Melalui team teaching tujuan layanan lembaga dapat tercapai dengan lebih baik.

Kegiatan team teaching memberikan kesempatan pendidik untuk dapat saling menghargai, saling melengkapi, dan saling belajar untuk meningkatkan kompetensi masing-masing dalam memberikan layanan Pendidikan Anak Usia Dini. Pendidik dapat menjadi pendengar yang baik ketika salah satu rekannya menyampaikan instruksi atau materi di depan. Pendidik dapat melengkapi informasi atau ilmu yang belum tersampaikan oleh rekannya. Pendidik dapat belajar memahami kondisi peserta didik ketika mereka diberi instruksi sehingga dapat belajar mengkondisikan kelas.

Faktor-Faktor yang Mendukung dan Menghambat Keefektifan Team Teaching

Keefektifan team teaching dipengaruhi beberapa hal. Pemahaman pendidik tentang team teaching memengaruhi perencanaan, pelaksanaan dan evaluasi kegiatan. Masing-masing hal berhubungan satu sama lain dan masing-masing memberikan kontribusi.

Pemahaman yang baik akan berpengaruh pada perencanaan yang baik. Pemahaman dan perencanaan yang baik akan memberikan pengaruh dalam pelaksanaan. Pelaksanaan yang berjalan baik akan memberikan hasil yang baik pula.

Ketersediaan sarana prasarana, keber-adaan mitra yang terbuka, jumlah dan ragam usia anak akan menentukan team teaching.

\section{SIMPULAN DAN SARAN}

\section{Simpulan}

Team teaching pendidik program PPAUD di Kabupaten Kulon Progo berjalan dengan sangat efektif. Komponen team teaching mulai dari pemahaman, perencanaan, pelaksanaan, evaluasi termasuk dalam kategori sangat efektif. Team teaching memberikan hasil yang baik dalam persepsi pengelola, orangtua dan memberikan suasana pembelajaran yang menyenangkan untuk anak.

\section{Saran}

Team teaching mempunyai faktor pendukung dan faktor penghambat, agar pelaksanaan dan hasil lebih optimal maka faktor pendukung harus dimaksimalkan dan faktor penghambat harus ditekan. Keterbatasan jumlah pendidik merupakan faktor penghambat team teaching. Jumlah pendidik yang terbatas di lembaga menjadikan team teaching tidak berjalan dengan optimal, maka disarankan jumlah pendidik ditambah. Penambahan jumlah pendidik akan memungkinkan terbentuknya tim pendidik.

Keterbatasan sarana dan prasarana menjadikan team teaching tidak berjalan dengan baik. Pembelajaran dengan team teaching memerlukan ruang tersendiri untuk setiap tim dan kelompok anak. Pemisahan ruang akan memberikan keleluasaan dan konsentrasi lebih pada anak, sehingga pembelajaran akan berjalan dengan baik dan anak tidak saling terganggu kegiatan di kelompok yang lain. Penambahan dan pelengkapan sarana dan prasarana perlu dilakukan agar team teaching dapat berjalan dengan optimal.

\section{DAFTAR PUSTAKA}

Arikunto, S. \& Abdul Jabar, C.S. (2010). Evaluasi program pendidikan: pedoman praktis bagi mahasiswa dan praktisi pendidikan. Jakarta: Bumi Aksara. 
Beggs, D.W. (1964). Team teching bold new venture. Bloomington \& London: Indiana University Press.

Dopyera, M.L. \& John, (1993). Becoming a teacher of young children, $5^{\text {th }}$ edition, Singapore: McGraw-Hill Inc.

Fitzpatrick, J.L \& Sanders, J.R. \& Worthen, B.R. (2011). Program evaluation alternative approaches and practical guidelines. New Jersey: Pearson.

Fridani, L. \& APE Lestari, (2009). Inspiring education PAUD pendidikan anak usia dini, Jakarta: Gramedia.

Goetz, K. (200o). Perspectives on team teaching. Artikel. Diambil pada tanggal 30 Juli 2012 dari http://www.ucalgary.ca/ egallery.

Kementerian Pendidikan Nasional, (2009) Peraturan menteri pendidikan nasional no 58 Tahun 2009 tentang standar pendidikan anak usia dini.
McCawley, P. F. (2002). The logic model for program planning and evaluation. Idaho: University of Idaho.

Morrison, G., (1976). Early childhood education today $4^{\text {th }}$ edition. Ohio: Merril Publishing Company.

Nevin, A., Villa, R. A \& Thousand, J.S. (2009). A guide to co-teaching with paraeducators: practical tips fir $K-12$ educators. California: Corwin Press.

Nielsen, D.M., (2008). Mengelola kelas untuk guru TK. (Terjemahan Febrianti Ika Dewi). California: A Sage Publications Company. (Buku asli diterbitkan 2006).

Sudjana. (2000). Manajemen program pendidikan. Bandung: Falah Production.

Sujiono, Y.N. (2009). Konsep dasar pendidikan anak usia dini. Jakarta: Indeks . (2008). Pedoman operasional layanan PPAUD, Jakarta: Depdiknas 